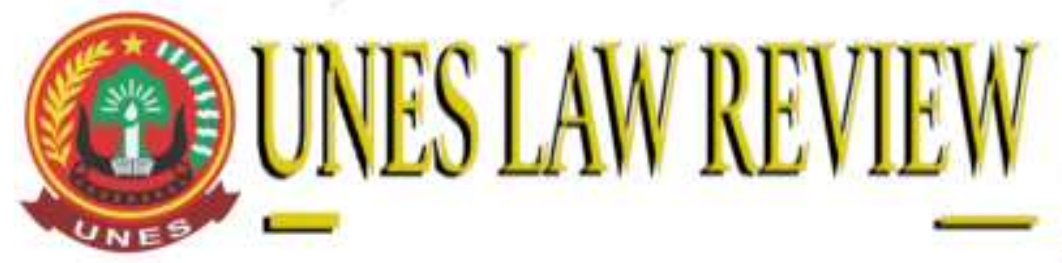

$+6282287504359$

+6282287504359

https://review-unes.com/

uneslawreview@gmail.com

DOI: https://doi.org/10.31933/unesrev.v3i3

Diterima: 15/12/2020, Diperbaiki: 24/05/2021, Diterbitkan: 26/05/2021

\title{
PENATAAN HAK ASASI ATAS PENDIDIKAN SAAT PANDEMI CORONA VIRUS DISEASE 2019 DI KOTA AMBON
}

\author{
${ }^{1)}$ Johanis S. F. Peilouw, ${ }^{2)}$ Dazonda R. Pattipawae, ${ }^{3)}$ Henry J. Pieris \\ 1) - 3) Universitas Pattimura, Ambon, Maluku, Indonesia \\ Corresponding Author: Johanis
}

\section{ABSTRACT}

The occurrence of the coronavirus 19 pandemic has caused all aspects of life to experience a downturn, including the fulfillment of the right to education. The purpose of the study was to study and analyze the impact of the covid 19 pandemic on the fulfillment of the right to education and to examine and analyze the arrangement of the right to education in the covid 19 pandemic in Ambon City. The research method used is normative legal research. The results of the study show that: 1) the impact of the Covid 19 Pandemic on the fulfillment of the Right to Education is that there is a gap in the process of fulfilling the right to education among students caused by students' economic problems, limited facilities to support the learning process from home, limited ability in mastering technology. 2) The structuring of the right to education in the Covid 19 pandemic in Ambon City is carried out through 2 (two) learning methods applied, namely online (online) and visits by teachers to students' homes.

Keywords: Structuring, Human Rights to Education, Pandemic Covid 19

\section{ABSTRAK}

Terjadinya pandemic virus corona 19 telah menyebabkan semua aspek kehidupan mengalami keterpurukan termasuk pemenuhan hak atas pendidikan. Tujuan penelitian untuk mengkaji dan menganalisis dampak pandemi covid 19 terhadap pemenuhan hak pendidikan dan untuk mengkaji dan menganalisis penataan hak atas pendidikan dalam pandemi covid 19 di Kota Ambon. Metode penelitian yang digunakan adalah penelitian hukum normatif. Hasil penelitian menunjukan bahwa: 1) dampak Pandemi Covid 19 terhadap pemenuhan Hak Pendidikan adalah adanya kesenjangan dalam proses pemenuhan hak atas pendidikan diantara siswa yang disebabkan karena masalah ekonomi siswa, keterbatasan sarana untuk menunjang proses belajar dari rumah, keterbatasan kemampuan dalam penguasaan teknologi. 2) Penataan Hak Atas Pendidikan Dalam Pandemi Covid 19 di Kota Ambon dilakukan melalui 2 (dua) metode pembelajaran yang diterapkan yakni secara online (daring) dan kunjungan yang dilakukan guru ke rumah siswa.

Kata Kunci: Penataan, Hak Asasi Atas Pendidikan, Pandemic Covid 19 


\section{PENDAHULUAN}

Corona Virus Disease (covid-19) saat ini telah menjangkiti seluruh dunia sejak pertama kali ditemukan di Wuhan China di akhir tahun 2019 dan secara cepat menyebar termasuk di Indonesia. Kondisi tersebut membuat Pemerintah menetapkan Pandemi Corona Virus Disease (Covid-19) sebagai bencana nasional berdasarkan Keputusan Presiden Nomor 11 Tahun 2020 tentang Penetapan Kedaruratan Kesehatan Masyarakat Corona virus Disease 2019 (Covid-19), serta menetapkan Peraturan Pemerintah Nomor 21 Tahun 2020 tentang Pembatasan Sosial Berskala Besar Dalam Rangka Percepatan Penanganan Corona virus Disease 2019 (Covid-19), dan Peraturan menteri kesehatan Nomor 9 tahun 2020 tentang Pedoman PSBB dalam rangka Percepatan Penanganan COVID-19 penyebaran Corona Virus Disease 2019 (COVID- 19).

Dampak terjadinya pandemic virus corona 19 telah menyebabkan semua aspek kehidupan mengalami keterpurukan, salah satunya adalah di bidang pendidikan, yaitu untuk mengurangi angka penyebaran Covid-19 maka pelaksanaan kegiatan belajar mengajar dilaksanakan dengan sistem online atau sistem dalam jaringan (daring) sejak bulan Maret 2020.

Sistem pembelajaran tersebut dilakukan tanpa tatap muka secara langsung, melainkan dilakukan dengan sistem pembelajaran jarak jauh. Dengan sistem pembelajaran jarak jauh, peserta didik tidak diharuskan atau diwajibkan untuk datang ke sekolah maupun kampus untuk melaksanakan pembelajaran.

Banyak sarana yang pada akhirnya dimanfaatkan oleh tenaga pendidik untuk melaksanakan kegiatan belajar mengajar secara jarak jauh. Sarana pembelajaran jarak jauh tersebut tidak dapat dihindari dari perkembangan teknologi informasi dan komunikasi. Sarana pembelajaran tersebut di antaranya aplikasi google meet, aplikasi zoom, google classroom, youtube, televisi, maupun media sosial whatsapp. Di mana semua sarana tersebut dihasilkan dari perkembangan teknologi informasi dan komunikasi yang semakin maju.

Sistem pembelajaran jarak jauh dalam pelaksanaan berdampak pada ketersediaan sarana dan prasaran penunjang seperti adanya wifi, pulsa data, computer atau hand phone yang harus dimiliki oleh pendidik maupun peserta didik. Namun, banyak daerah-daerah yang memiliki akses internet kurang baik atau tidak lancar sehingga menjadi salah satu kendala berlangsungnya kegiatan belajar mengajar dengan baik.

Kota Ambon di Provinsi Maluku merupakan salah satu daerah di Indonesia yang telah mendapat persetujuan menerapkan Pembatasan Sosial Berskala Besar (PSBB) di Kota Ambon oleh Menteri Kesehatan Republik Indonesia berdasarkan keputusan Nomor HK.01.07/ MENKES/358/2020 tentang Penetapan Pembatasan Sosial Berskala Besar di Wilayah Kota Ambon, Provinsi Maluku dalam rangka percepatan penanganan Corona Virus Desease 2019 (COVID-19).

Pemberlakuan PSBB membuat proses pembelajaran yang dilakukan secara tatap muka dihentikan dan menggunakan sistem daring/online atau jarak jauh. Sistem pembelajaran jarak jauh tidak menutup kemungkinan akan timbulnya beberapa masalah-masalah dalam berlangsungnya proses pembelajaran. Dengan pelaksanaan pembelajaran jarak jauh ini, tentunya peserta didik maupun tenaga pendidik dari semua kalangan diharuskan memiliki akses jaringan 
internet yang baik. Namun, banyak daerah-daerah yang memiliki akses internet kurang baik atau tidak lancar sehingga menjadi salah satu kendala bagi berlangsungnya kegiatan belajar mengajar dengan baik.

Hal tersebut juga disampaikan oleh Kepala Dinas Pendidikan dan Olah raga Kota Ambon (Kadispora Kota Ambon) yang menyatakan bahwa kendala yang dihadapi yakni keterbatasan akses internet dan fasilitas yang dimiliki siswa, perangkat ponsel android maupun laptop. Lebih lanjut Kadispora Kota Ambon bahwa tidak bisa sepenuhnya menerapkan sistem daring, karena tidak semua orang tua siswa memiliki penghasilan yang sama, bahkan dalam satu keluarga ada yang memiliki tiga anak jika sistem daring maka yang terjadi keterbatasan fasilitas ponsel android maupun laptop. Hal ini diperlukan solusi dari pemerintah terkait dengan pemenuhan hak pendidikan bagi peserta didik di masa pandemi covid 19 di Kota Ambon. Berdasarkan hal tersebut maka akan dilakukan pengkajian terhadap dampak pandemi covid 19 terhadap pemenuhan hak pendidikan dan bagaimana penataan hak atas pendidikan dalam pandemi covid 19 di Kota Ambon.

\section{METODE PENELITIAN}

Metode penelitian yang digunakan adalah penelitian hukum normatif, yakni suatu penelitian yang terutama mengkaji ketentuan-ketentuan hukum positif, asas- asas hukum, prinsip-prinsip hukum maupun doktrin hukum guna menjawab isu hukum yang dihadapi (Peter Mahmud Marzuki, 2005:35), dengan pendekatan peraturan perundang-undangan dan pendekatan konseptual. Selain itu, juga dilakukan wawancara terhadap stakeholders yang terkait dengan pelaksanaan pendidikan di kota ambon untuk mendapatkan informasi mengenai perkembangan dan pelaksanaan pendidikan dimasa pandemic covid 19.

\section{HASIL DAN PEMBAHASAN}

\section{Dampak Pandemi Virus Covid 19 Terhadap Pemenuhan Hak Atas Pendidikan}

\section{Hak Atas Pendidikan}

Hak atas pendidikan (HAP) tidak dapat dilepaskan dari hak asasi manusia (HAM) pada umumnya. Dalam konteks akademik, HAM biasa dikelompokkan ke dalam dua bidang, yaitu HAM Sipil dan Politik (Sipol) dan HAM Ekonomi, Sosial, dan Budaya (Ekosob). Dalam pembagian HAM tersebut, HAP merupakan bagian dari kelompok HAM Ekosob (Hernadi Affandi, 2017:220) .

Pendidikan merupakan salah satu hak asasi manusia yang merupakan bagian dari hak ekonomi, sosial dan budaya atau hak Ekosob. Pasal 26 Deklarasi Hak Asasi Manusia mengatur mengenai jaminan hak atas pendidikan menyatakan: "Setiap orang berhak atas pendidikan. Pendidikan harus bebas biaya, setidaknya pada tingkat dasar dan tingkat rendah. Pendidikan dasar harus bersifat wajib. Pendidikan teknik dan profesi harus tersedia secara umum dan pendidikan yang lebih tinggi harus sama- sama dimasuki semua orang berdasarkan kemampuan" (Akhmad Budi Cahyono dkk, 2008:10) .

Dalam perkembangan hukum internasional, Indonesia telah meratifikasi kovenan internasional Ekonomi Sosial dan Budaya dan Kovenan Sipil dan Politik pada bulan 
September 2005. Pasal 13 dan 14 Kovenan Internasional Ekonomi Sosial dan Budaya, secara khusus diatur tentang hak atas pendidikan bagi warga negara di satu sisi, yang di sisi lain adalah sebagai kewajiban negara untuk memenuhinya (state obligation). Dalam pasal 13 ayat 1 Kovenan Internasional Ekonomi Sosial dan Budaya dinyatakan:

"The states Parties to the present Covenant recognize the right of everyone to education. They agree that education shall be directed to the full development of the human personality and the sense of its dignity, and shall strengthen the respect for human rights and fundamental freedoms. They further agree that education shallenable all persons to participate effectively in a free society, promote understanding, tolerance and frienship among all nations and all racial, ethnic or religious groups, and further the activities of the United Nation for the maintenance of peace”.

Jaminan perlindungan terhadap HAM juga merupakan bagian dari materi muatan Undang-Undang Dasar Negara Republik Indonesia Tahun 1945 (UUD NRI Tahun 1945). Menurut J.G Steenbeek (2005:16), materi muatan konstitusi adalah:

a. Adanya jaminan terhadap Hak Asasi Manusia warga negaranya

b. Ditetapkan susunan ketatanegaraan suatu negara yg fundamental

c. Adanya pembagian dan pembatasan tugas ketatanegaraan yang bersifat fundamental

Menurut Mariam Budiardjo dalam J.G Steenbeek (2005:17), bahwa materi muatan konstitusi adalah:

a. Organisasi negara, misalnya pembagian kekuasaan antara badan legislatif, eksekutif dan yudikatif, pembagian kekuasaan antara pemerintah federal dan pemerintah Negara bagian, prosedur penyelesaian masalah pelanggaran yuridiksi oleh suatu badan pemerintah dan sebagainya.

b. Hak Asasi Manusia

c. Prosedur mengubah Undang-Undang Dasar

d. Adakalanya memuat larangan untuk mengubah sifat tertentu dari Undang- Undang Dasar.

Hal tersebut menujukan bahwa salah satu substansi yang diatur dalam konstitusi adalah mengenai HAM. Sementara itu, secara khusus pengaturan HAM dalam bidang pendidikan dapat dilihat dalam tujuan Negara. yang diatur dalam alinea ke 4 pembukaan UUDNRI Tahun 1945 yang menyebutkan bahwa: Kemudian dari pada itu untuk membentuk suatau Pemerintahan Negara Indonesia yang melindungi segenap bangsa Indonesia dan seluruh tumpah darah Indonesia dan untuk memajukan kesejahteraan umum, mencerdaskan kehidupan bangsa, dan ikut melaksanakan ketertiban dunia yang berdasarkan kemerdekaan, perdamaian abadi dan keadilan social.

Menurut Harold J. Laski yang dikutip oleh Miriam Budiardjo bahwa tujuan negara adalah menciptakan keadaan dimana rakyatnya dapat mencapai terkabulnya keinginankeinginan secara maksimal (creation of those conditions under which the members of the state may attain the maximum satisfaction of their desires) (Emmanuel Sujatmoko, 2010:199) .

Dengan demikian, mencerdaskan kehidupan bangsa merupakan perwujudan dari prinsip dan keinginan Negara untuk membuat rakyat menjadi cerdasa melalui sarana 
peningkatan pelayanan di bidang pendidikan.

Lebih lanjut hak atas pendidikan sebagai bagian dari HAM juga diatur dalam Pasal 31 UUD NRI Tahun 1945 yang menyatakan bahwa:

a. Setiap warga Negara berhak mendapat pendidikan.

b. Setiap warga Negara wajib mengikuti pendidikan dasar dan pemerintah wajib membiayainya.

c. Pemerintah mengusahakan dan menyelenggarakan satu system pendidikan nasional yang meningkatkan keimanan dan ketakwaan serta akhlak mulia dalam rangka mencerdaskan kehidupan bangsa yang diatur dengan undang-undang

d. Negara memprioritaskan anggaran pendidikan sekurangkurangnya $20 \%$ dari anggaran pendapatan dan belanja Negara serta dari anggaran pendapatan dan belanja 11 daerah untuk memenuhi kebutuhan penyelenggaraan pendidikan nasional

e. Pendidikan memajukan ilmu pengetahuan dan teknologi dengan menjunjung tinggi nilainilai agama dan persatuan bangsa untuk kemajuan peradaban serta kesejahteraan umat manusia.

Pasal 28 C ayat (1) UUD NRI Tahun 1945 menyatakan bahwa "Setiap orang berhak mengembangkan diri melalui pemenuhan kebutuhan dasarnya, berhak mandapat pendidikan dan memperoleh manfaat dari ilmu pengetahuan dan teknologi, seni dan budaya, demi meningkatkan kualitas hidupnya dan demi kesejahteraan umat manusia”.

Lebih lanjut dalam Pasal 12 Undang-Undang Nomor 39 tahun 1999 tentang Hak Asasi Manusia (UU HAM) mengatur: "Setiap orang berhak atas perlindungan bagi pengembangan pribadinya, untuk memperoleh pendidikan, mencerdaskan dirinya, dan meningkatkan kualitas hidupnya agar menjadi manusia yang beriman, bertaqwa, bertanggung jawab, berakhlak mulia, bahagia, dan sejahtera sesuai dengan hak asasi manusia".

Pasal 1 angka 18 Undang-undang No. 20 tahun 2003 tentang Sistem Pendidikan Nasional "Wajib belajar adalah program pendidikan minimal yang harus diikuti oleh warga Negara Indonesia atas tanggung jawab pemerintah dan pemerintah daerah"

Berbagai pengaturan tersebut menujukan bahwa semua warga negara, terutama peserta didik dijamin oleh UUD NRI Tahun 1945 untuk mendapat hak dan peluang yang sama dalam memperoleh dan mengakses pendidikan di Indonesia.

Menurut Emmanuel Sujatmoko bahwa Pendidikan memegang peranan utama untuk menjamin kelangsungan hidup bangsa dan negara, karena pendidikan merupakan wahana untuk meningkatkan dan mengembangkan kualitas sumber daya manusia. Atas hal tersebut maka pengaturan hak-hak warga atas pendidikan diatur dalam kostitusi sebagai bentuk jaminan kepastian hukum dan wujud pengakuan negara terhadap hak-hak warga negaranya. Dalam proses penyelenggaraan pendidikan di Indonesia, kewajiban negara dalam pemenuhan hak atas pendidikan dasar tersebut diatur dalam Undang-undang Dasar Negara Republik Indonesia Tahun 1945 dan beberapa peraturan perundang-undangan lainnya yang berkaitan dengan pemenuhan hak atas pendidikan dasar. 


\section{Dampak Pandemi Virus Covid 19 Terhadap Hak Pendidikan}

Pandemi COVID-19 merupakan musibah yang menjangkau seluruh penduduk bumi., seluruh segmen kehidupan manusia di bumi terganggu, tanpa kecuali pendidikan. Banyak negara memutuskan menutup sekolah, perguruan tinggi maupun universitas, termasuk Indonesia (Rizqon Halal Syah Aji, 2020:396).

Data UNESCO yang menunjukkan bahwa pada bulan April terdapat 1,6 miliar pelajar diliburkan dari sekolah dan universitas karena langkah-langkah untuk menekan penyebaran Covid-19. Angka tersebut merupakan sekitar $90 \%$ dari seluruh populasi siswa di dunia.

Penutupan dan penghentian aktivitas pendidikan dilakukan sebagai salah satu sarana untuk memutus rantai penyebaran virus corona 19, sebagaimana juga diatur dalam Pasal 59 ayat (3) Undang-undang nomor 6 Tahun 2018 Tentang Kekarantinaan Kesehatan yang mengatur bahwa Pembatasan Sosial Berskala Besar paling sedikit meliputi:

a) peliburan sekolah dan tempat kerja;

b) pembatasan kegiatan keagamaan; dan/atau

c) pembatasan kegiatan di tempat atau fasilitas umum.

Pandemi virus Covid-19 yang sangat mendadak menyebabkan dunia pendidikan Indonesia perlu mengikuti alur yang sekiranya dapat menolong kondisi sekolah dalam keadaan darurat. Sekolah perlu memaksakan diri menggunakan media daring. Namun penggunaan teknologi bukan tidak ada masalah, banyak varians masalah yang menghambat terlaksananya efektivitas pembelajaran dengan metode daring diantaranya adalah:

a Keterbatasan Penguasaan Teknologi Informasi oleh Guru dan Siswa Kondisi guru di Indonesia tidak seluruhnya paham penggunaan teknologi, ini bisa dilihat dari guru-guru yang lahir tahun sebelum 1980-an. Kendala teknologi informasi membatasi mereka dalam menggunakan media daring. Begitu juga dengan siswa yang kondisinya hampir sama dengan guru-guru yang dimaksud dengan pemahaman penggunaan teknologi.

b. Sarana dan Prasarana yang Kurang Memadai Perangkat pendukung teknologi jelas mahal. Banyak di daerah Indonesia yang guru pun masih dalam kondisi ekonominya yang menghawatirkan. Kesejahteraan guru maupun murid yang membatasi mereka dari serba terbatas dalam menikmati sarana dan prasarana teknologi informasi yang sangat diperlukan dengan musibah Covid-19 ini.

c. Akses Internet yang terbatas Jaringan internet yang benar-benar masih belum merata di pelosok negeri. Tidak semua lembaga pendidikan baik Sekolah dasar maupun sekolah menengah dapat menikmati internet. Jika ada pun jaringan internet kondisinya masih belum mampu mengkover media daring.

d. Kurang siapnya penyediaan Anggaran Biaya juga sesuatu yang menghambat karena, aspek kesejahteraan guru dan murid masih jauh dari harapan. Ketika mereka menggunakan kuota internet untuk memenuhi kebutuhan media daring, maka jelas mereka tidak sanggup membayarnya. Ada dilema dalam pemanfaatan media daring, ketika menteri pendidikan memberikan semangat produktivitas harus melaju, namun disisi lain kecakapan dan kemampuan finansial guru dan siswa belum melaju ke arah yang sama. Negara pun belum 
hadir secara menyeluruh dalam memfasilitasi kebutuhan biaya yang dimaksud.

Selain itu, proses belajar dari rumah di tengah pandemi virus corona dengan kendala infrastruktur dan teknologi telah berdampak terhadap adanya kesenjangan pendidikan antar siswa, antar sekolah maupun antar daerah.

Kesenjangan diantara sekolah terlihat pada sekolah swasta dan sekolah negeri. Hasil wawancara dengan salah satu masyarakat menyatakan bahwa dalam pelaksanaan pembelajaraan dimasa pandemic covid 19 di sekolah swasta lebih terorganisasi, rapih dan ditunjang dengan sarana dan prasarana yang cukup baik untuk mendukung proses belajar mengajar secara online, hal sebaliknya terjadi pada sekolah negeri yang kewalahan dalam pelaksanaan pendidikan dimasa pandemic covid 19, baik itu dari aspek ketersediaan sarana pembelanjaran secara online mapun kemampuan sumber daya manusia tenaga pengajar dalam pemanfaatan teknologi informatika.

Hal ini berdampak terhadap aktivitas pada saat proses belajar mengajar yang hanya terfokus pada pemberian tugas dari guru pada siswa sehingga para siswa juga mengalami kendala dalam proses tersebut karena banyaknya tugas yang harus dibuat tanpa adanya proses penjelasan terhadap materi pembelajaran.

Selain itu, masalah pembiayaan dalam proses belajar mengajar berpengaruh proses pembelajaran secara online sehingga adanya keterbatasan siswa yang terlibat dalam dalam proses pembelajaran yang dilakukan oleh sekolah. Hal ini memberikan dampak pada kelancaran proses belajar mengajar karena tidak semua siswa memiliki sarana penunjang belajar secara online, misalnya handphone berbasis android.

Hal ini menunjukan bahwa kesenjangan yang terjadi antar siswa dan sekolah dalam proses pembelajaran online dimasa pandemic covid 19 dilatar belakangi oleh:

1) adanya masalah ekonomi siswa, dikarenakan kemampuan orang tua siswa dalam membiayai penyediaan sarana pembelajaran. Dimana ada orang tua siswa yang tidak mampu menyediakan sarana pembelajaran seperti handphone berbasis adroid maupun laptop

2) ketersediaan sarana pembelajaran yang kurang memadai untuk menunjang proses belajar dari rumah, misalnya terbatasnya akses internet (kuota data yang terbatas), sering terjadinya gangguan signal internet, serta adanya sarana pembelajaran yang digunakan bersama oleh beberapa orang siswa.

3) Keterbatasan dalam penguasaan teknologi informasi oleh guru, orang tua dan siswa Kondisi ini menunjukan bahwa keberadaan teknologi di masa pandemic covid 19 memiliki dampak, disatu sisi teknologi sangat membantu proses belajar mengajar agar tetap berlangsung, akan tetapi disisi yang lain keterbatasan sarana teknologi yang terbatas memberi dampak terhadap keterbatasan siswa dalam berpartisipasi pada proses belajar, dan ketidakmampuan dalam penguasaan teknologi berdampak pada proses pembelajaran yang berlangsung tidak maksimal. 


\section{Penataan Hak Atas Pendidikan Dalam Pandemi Covid 19 di Kota Ambon}

Pasal 12 Undang-Undang HAM menyatakan bahwa: setiap orang berhak atas perlindungan bagi pengembangan pribadinya, untuk memperoleh pendidikan, mencerdaskan dirinya, dan meningkatkan kualitas hidupnya agar menjadi manusia yang beriman, bertaqwa, bertanggung jawab, berakhlak mulia, bahagia, dan sejahtera sesuai dengan hak asasi manusia.

Selanjutnya dalam Pasal 60 ayat (1) Undang-Undang HAM menyatakan bahwa setiap anak berhak untuk memperoleh pendidikan dan pengajaran dalam rangka pengembangan pribadinya sesuai dengan minat, bakat, dan tingkat kecerdasannya. Sementara itu, Pasal 64 Undang-Undang HAM menyatakan bahwa setiap anak berhak untuk memperoleh perlindungan dari kegiatan eksploitasi ekonomi dansetiap pekerjaan yang membahayakan dirinya, sehingga dapat mengganggu pendidikan, kesehatan fisik, moral, kehidupan sosial, dan mental spiritualnya.

Dalam kaitan dengan hal tersebut juga diatur kewajiban dan tanggung jawab Pemerintah untuk memberikan perlindungan HAM termasuk HAM di bidang pendidikan yaitu dalam Pasal 71 UU HAM yang menyatakan bahwa Pemerintah wajib dan bertanggung jawab menghormati, melindungi, menegakkan, dan memajukan hak asasi manusia yang diatur dalam Undang-undang ini, peraturan perundang-undangan lain, dan hukum internasional tentang hak asasi manusia yang diterima oleh negara Republik Indonesia.

Selanjutnya dalam Pasal 72 UU HAM menyatakan bahwa kewajiban dan tanggung jawab Pemerintah sebagaimana dimaksud dalam Pasal 71, meliputi langkah implementasi yang efektif dalam bidang hukum, politik, ekonomi, sosial, budaya, pertahanan keamanan negara, dan bidang lain.

Adapun hal-hal yang wajib dilakukan oleh semua steakholders pendidikan adalah;

1. Pemerintah Peran pemerintah sangat penting dan fundamental. Alokasi anggaran yang sudah diputuskan oleh Instruksi Presiden Nomor 4 tahun 2020 tentang refocussing kegiatan, relokasi anggaran, serta pengadaan barang dan jasa dalam rangka percepatan penanganan Covid-19 harus segera dilaksanakan.

2. Orang Tua Orang tua sebagai pendidik utama di rumah tangga harus menjalankan fungsinya. Meskipun demikian tetap saja bantuan guru di sekolah perlu hadir door to door disemua peserta didik. Ini harus membuka cakrawala dan tanggungjwab orang tua bahwa pendidikan anaknya harus dikembalikan pada effort orang tua dalam mendidikan mental, sikap dan pengetahuan anakanaknya.

3. Langkah pembelajaran daring harus seefektif mungkin. Guru bukan membebani murid dalam tugas-tugas yang dihantarkan dalam belajar di rumah. Jika perlu guru hadir secara gagasan dalam door to door peserta didik. Guru bukan hanya memposisikan sebagai pentransfer ilmu, tetapi tetap saja mengutamakan ing ngarso sung tulada, ing madya mangun karsa, tut wuri handayani.

4. Sekolah Sekolah sebagai lembaga penyelenggara pendidikan harus bersiaga memfasilitasi perubahan apapun menyangkut pendidikan siswanya. Pendidikan tingkah laku harus menjadi pijakan kuat ditengah perkembangan teknologi dan arus percepatan informasi. Programprogram pendidikan yang dilakukan sekolah harus benar-benar disampaikan kepada murid, 
terlebih dengan media daring tetap saja pihak sekolah harus benar- benar memperhatikan etika sebagai lembaga pendidikan. Penekanan belajar dirumah kepada murid harus benarbenar mendapat kawalan agar guru-guru yang mengajar melalui media garing tetap smooth dan cerdas dalam menyampaikan pelajaran-pelajaran yang wajib dipahami oleh murid.

Berbagai kebijakan pemda kota ambon dalam memenuhi hak siswa atas pendidikan dimasa pandemic covid 19 merupakan usaha pemerintah agar HAM di bidang pendidikan tidak diabaikan. Hwian Christianto menyatakan bahwa Pembatasan sosial (social distancing) tidak boleh dimaknai pengurangan hak atas pendidikan. Strategi PSBB sebagaimana digambarkan dalam Undang-Undang Kekarantinaan Kesehatan sama sekali tidak mengecualikan hak atas pendidikan, sebaliknya, dalam masa PSBB hak atas pendidikan harus tetap dapat terpenuhi semaksimal mungkin.

Hal tersebut selaras dengan ketentuan Pasal 8 UU HAM yang menyatakan bahwa Perlindungan, pemajuan, penegakan, dan pemenuhan hak asasi manusia terutama menjadi tanggung jawab Pemerintah

Berdasarkan hal tersebut maka penataan terhadap hak pendidikan siswa perlu dilakukan oleh Pemda Kota Ambon. Dalam kaitan dengan hal tersebut maka penanganan dampak Covid-19 pada dunia pendidikan dilakukan melalui kebijakan pemerintah dan pelaksanaannya operasionalisasi di lapangan. Kepala Disdik Kota Ambon, Fahmy Salatalohy menyatakan bahwa ada 2 (dua) metode pembelajaran yang ditetapkan yakni secara daring dan jemput bola guru ke rumah siswa. 2 (dua) metode belajar ini merupakan hasil evaluasi dan koordinasi tim Gugus Tugas Percepatan Penanggulangan Covid-19 Kota Ambon dengan seluruh kepala sekolah. Untuk metode jemput bola, guru datang ke rumah siswa menyampaikan tugas, serta membuat dan menyusun jadwal berkelompok belajar dengan melihat kondisi di lapangan. "Dua metode pembelajaran ini merupakan upaya agar seluruh siswa tetap melakukan aktivitas belajar di rumah masing-masing, baik melalui sistem daring maupun offline mengingat semua desa dan kelurahan di Ambon belum terhubung akses internet secara baik, terutama kecamatan yang jauh dari pusat kota.

Dua metode pembelajaran ini merupakan upaya agar seluruh siswa tetap melakukan aktivitas belajar di rumah masing-masing, baik melalui sistem daring maupun offline, sebagai upaya untuk mengantisipasi ketersediaan saran dan prasarana penunjang pembelajaran online yang tidak merata diantara siswa karena latar belakang kemampuan ekonomi orang tua siswa yang berbeda-beda sehingga aktivitas belajar online juga perlu ditunjang secara offline dengan cara adanya kunjungan para guru ke rumah siswa untuk memantau secara langsung perkembangan siswa dalam proses pembelajaran.

Berdasarkan 2 (dua) metode tersebut, maka dicoba untuk mengembangkan 2 (dua) metode dinas pendidikan kota ambon dalam penataan hak pendidikan dengan pelaksanaan sistem pembelajaran "sistem kubus pembelajaran" yang terkait dengan pengembangan hubungan siswa dengan pengajar baik secara online maupun offline dengan melibatkan orang tua dan tim pendamping. 
Hal ini dikembangkan dalam kaitan dengan proses pembelajaran di tingkat Sekolah Dasar (SD) maupun di tingkat Sekolah Menengah Pertama (SMP). Hal ini dikarenakan bahwa keberadaan siswa SD dan SMP perlu pendampingan yang lebih mendalam pada proses pembelajaran secara online sehingga peran tersebut tidak hanya diberikan pada guru tetapi juga pada orang tua dan tim pendamping.

Dalam hal ini peran orang tua adalah mendampingi siswa dalam proses belajar khsusnya jika dilakukan secara online, untuk itu orang tua juga perlu disiapkan dengan perangkan pembelajaran yang disiapkan oleh guru, sehingga dalam proses belajar orang tua dapat membantu menerjemahkan materi belajar yang disampaikan oleh guru pada siswa.

Hubungan tersebut dapat dilihat dalam diagram dibawah ini:

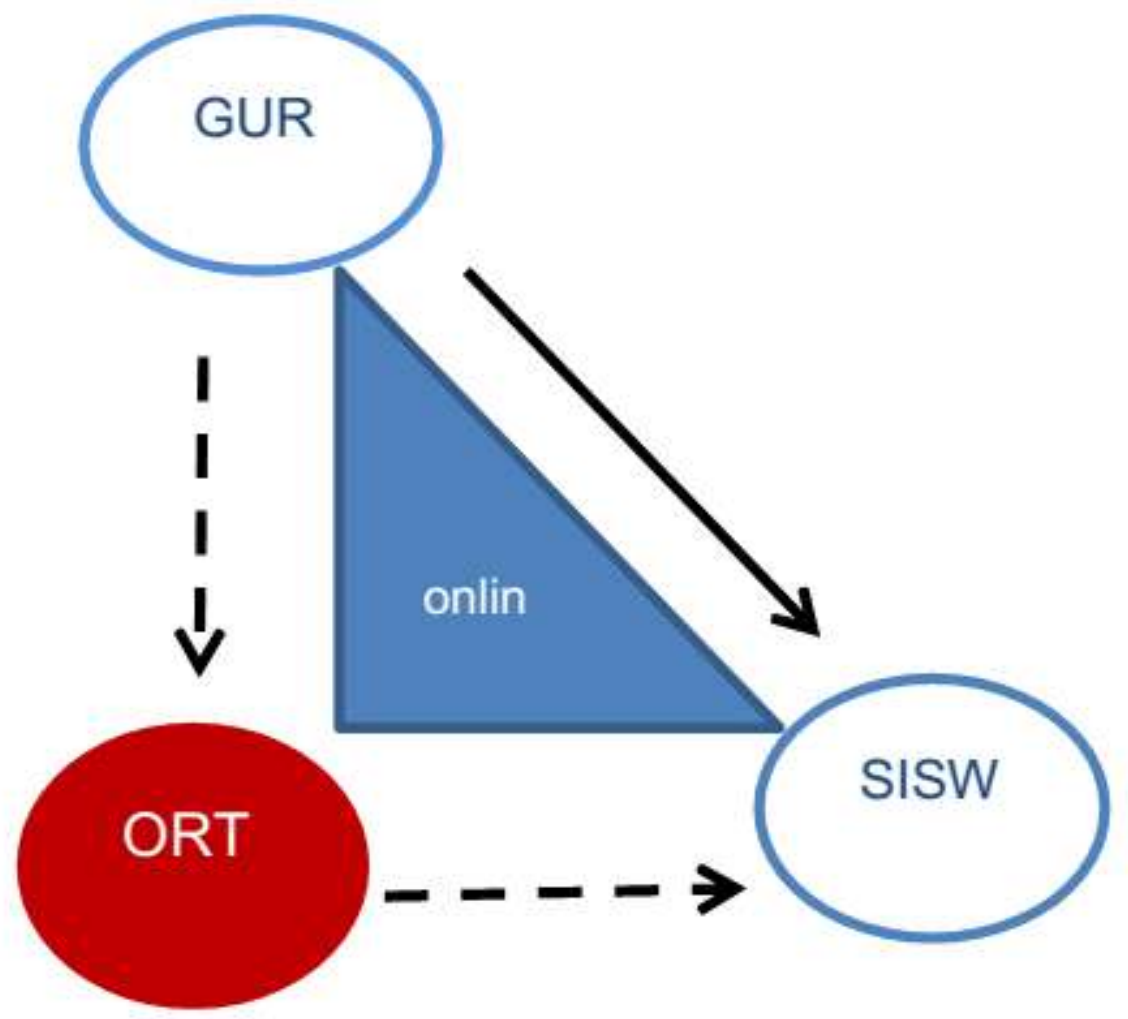

Sementara itu dalam sistem offline, guru melakukan kunjungan secara langsung kepada siswa. Untuk itu, perlu dibentuk kelompok-kelompok siswa untuk dapat dievaluasi secara langsung oleh guru. Sistem ini cukup penting untuk mengantisipasi kondisi siswa yang terbatas secara ekonomi dalam mengikuti pembelajaran secara online, sehingga adanya kunjungan guru pada siswa dapat menjembatani kebutuhan siswa secara umum.

Selain itu, keberadaan sistem ini perlu ditopang oleh tim pendamping yang bertugas sebagai mentor untuk mendampingi siswa dalam memberikan bimbingan selama proses pembelajaran, sehingga keberadaan guru hanya melakukan monitoring dan evaluasi melalui kunjungan tersebut. Keberadaan tim pendamping perlu juga ditunjang oleh adanya koordinasi dengan guru, serta adanya perangkat pembelajaran yang telah disiapkan oleh guru atau sekolah. 
Hal yang perlu diperhatikan dengan adanya keberadaan tim pendamping adalah dapat melibatkan perguruan tinggi melalui kerja sama untuk menyiapkan tim pendamping yang berasal dari mahasiswa sebagai mentor siswa selama proses pembelajaran dilakukan secara offline melalui kunjungan guru pada siswa. Hal ini dapat dilihat dalam diagram dibawah ini:

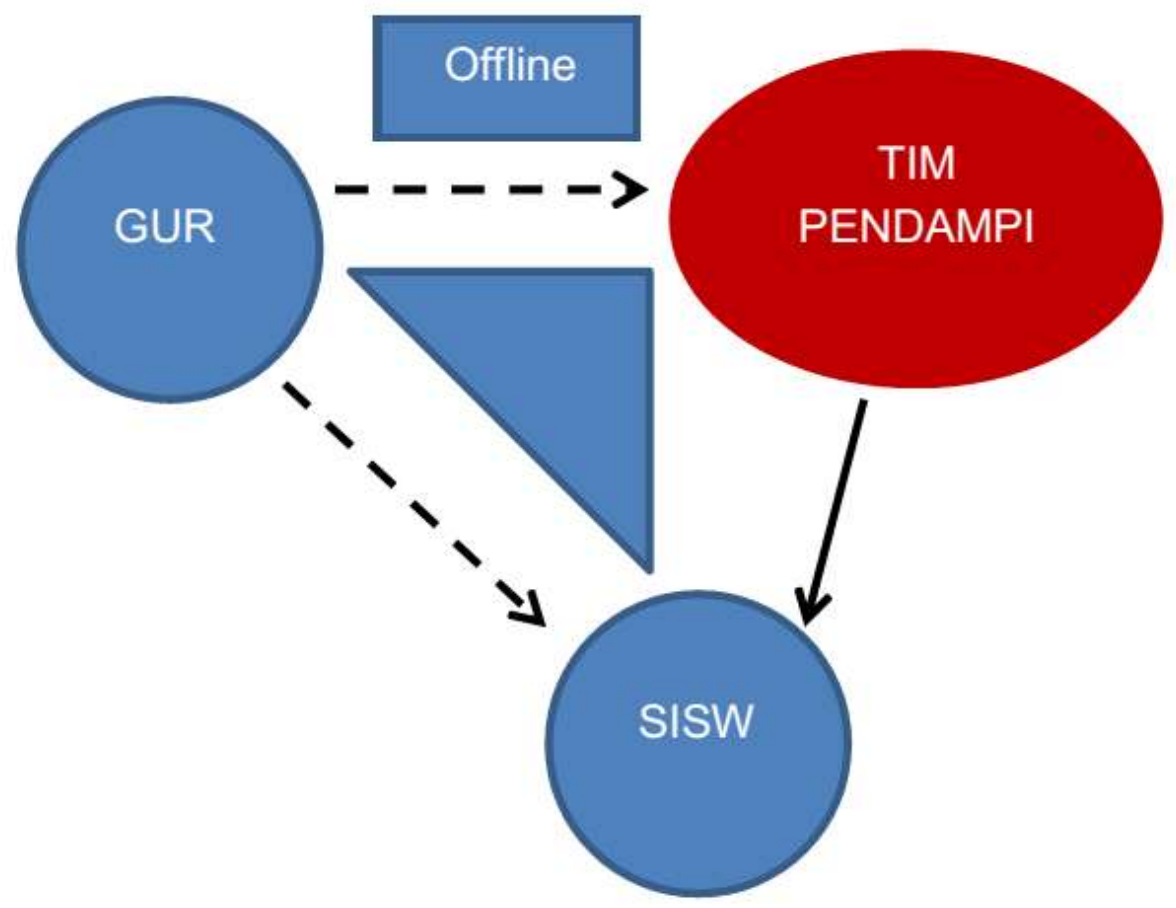

Melalui penataan sistem pendidikan yang dilakukan secara online dimasa pandemic covid 19 melalui sistem kubus pembelajaran, diharapkan pemenuhan hak asasi terhadap hak pendidikan siswa dapat dipenuhi.

\section{PENUTUP}

Berdasarkan hasil penelitian, maka kesimpulan yang dapat disampaikan adalah :

1. Dampak Pandemi Covid 19 terhadap pemenuhan Hak Pendidikan adalah adanya kesenjangan dalam proses pemenuhan hak atas pendidikan diantara siswa yang disebabkan karena masalah ekonomi siswa, keterbatasan sarana untuk menunjang proses belajar dari rumah, keterbatasan kemampuan dalam penguasaan teknologi. Hal tersebut terlihat pada sekolah swasta dan sekolah negeri, karena sekolah swasta siap dalam melakukan proses pembelajaran secara online baik tenaga pendidik maupun sarana dan serta kemampuan guru dan siswa.

2. Penataan Hak Atas Pendidikan Dalam Pandemi Covid 19 di Kota Ambon dilakukan melalui 2 (dua) metode pembelajaran yang diterapkan yakni secara online (daring) dan kunjungan yang dilakukan guru ke rumah siswa. 


\section{DAFTAR PUSTAKA}

Akhmad Budi Cahyono dkk, Laporan Penelitian Pelaksanaan Aksesibilitas Pendidikan Dasar Sebagai Pemenuhan Hak Atas Pendidikan Bagi Warga Negara (Untuk Satuan Pendidikan Sekolah Dasar), Subkomisi Pengkajian dan Penelitian Komisi Nasional Hak Asasi Manusia, 2008

Dahlam Thaib dkk, Teori dan Hukum Konstitusi, PT RajaGrafindo Persada, Jakarta, 2005

Emmanuel Sujatmoko, Hak Warga Negara Dalam Memperoleh Pendidikan, Jurnal Konstitusi, Volume 7, Nomor 1, Februari 2010

Hernadi Affandi, Tanggung Jawab Negara Dalam Pemenuhan Hak Atas Pendidikan Menurut Undang-Undang Dasar Tahun 1945, Jurnal Hukum Postitum, Vol. 1, No. 2, Juni 2017, Hal 218-243

Hwian Christianto, Penggunaan Media Internet Dalam Pemenuhan Hak Atas Pendidikan Di Masa Pandemi Covid-19: Perspektif Hak Asasi Manusia Dan Hukum Pidana, JURNAL HAM Volume 11, Nomor 2, Agustus 2020

Jimly Asshiddiqie, Pengantar HTN jilid II, Sekretariat Jenderal dan Kepaniteraan Mahkamah Konstitusi RI, Jakarta, 2006

Masyhur Effendi. Dimensi dan Dinamika Hak Asasi Manusia dalam Hukum Nasional dan Internasional, Jakarta, Ghalia Indonesia, 1994

M. Yasir Alimi, dkk, advokasi hak-hak perempuan, membela hak mewujudkan perubahan, LKiS, Yogyakarta, 1999

Mariam Budiardjo, 1982, Dasar-Dasar Ilmu Politik, Gramedia, Jakarta

Osgar S. Matompo, Pembatasan Terhadap Hak Asasi Manusia Dalam Prespektif Keadaan Darurat, Jurnal Media Hukum, Vol. 21 No.1 Juni 2014

Peter Mahmud Marzuki, Penelitian Hukum, Prenada Media, Cet. I, Jakarta,2005 Rizqon Halal Syah Aji, Dampak Covid-19 pada Pendidikan di Indonesia: Sekolah,

Keterampilan, dan Proses Pembelajaran, SALAM; Jurnal Sosial \& Budaya Syar-I, Vol. 7 No. 5 (2020), pp. 395-402

Soehino, 1998, Ilmu Negara, Liberty, Yogyakarta 